\title{
Antiproliferative effect of rosehip tea phenolics in prostate cancer cell lines
}

\section{Kuşburnu çayı fenoliklerinin prostat kanseri hücre hatlarındaki antiproliferatif etkisi}

https://doi.org/10.1515/tjb-2019-0262

Received March 21, 2019; accepted November 28, 2019;

published online September 3, 2020

\section{Abstract}

Objectives: Recently, phenolic compounds (quercetin, kaempferol, ellagic acid (EA), and myricetin) as natural sources have been suggested to be used for treatment and chemoprevention of prostate cancer. Since rosehip includes the above molecules in high concentration, we set out to investigate possible anti-proliferative effect of rosehip tea on the prostate cancer cell line.

Methods: The flavonol content of rosehip tea prepared at different temperatures and time intervals was determined first and then the antiproliferative effect of tea samples was established by adding tea samples to the prostate cancer cell line (VCaP and LNCaP).

Results: Quercetin was more effective in LNCaP cell than in VCaP cell $\left(\mathrm{IC}_{50}=20\right.$ and $200 \mu \mathrm{M}$, respectively). The boiled fruit shredded at minute 7 showed the highest levels of quercetin, EA and kaempferol and the boiled fruit at minute 7 had the highest levels of kaempferol and EA. The tea samples were prepared in concentrations relevant to their $\mathrm{IC}_{50}$ values, added to the VCaP and LNCaP cell lines. The antiproliferative effect of rosehip tea on VCaP cells was slightly greater than that of LNCaP cells.

*Corresponding author: Assoc. Prof. Ali Mert Özgönül, PhD, Ege University Faculty of Medicine, Medical Biochemistry, Izmir, Turkey, E-mail: a.mert.ozgonul@ege.edu.tr

Aycan Aşık and Cumhur Gündüz, Ege University Faculty of Medicine, Medical Biology, Izmir, Turkey. https://orcid.org/0000-0002-41234175 (A. Aşık)

Burak Durmaz, Ramin Aslaminabad and Eser Yıldırım Sozmen, Ege University Faculty of Medicine, Medical Biochemistry, Izmir, Turkey. https://orcid.org/0000-0002-6383-6724 (E.Y. Sozmen)
Conclusion: Each of the flavonols exhibits an antiproliferative effect. Our data clearly indicated that rosehip as a natural source of all flavonols had an antiproliferative effect on androgen-sensitive prostate cancer. Now that it is important to use natural sources in cancer, rosehip seems to be a promising natural product to be used to treat the prostate illness.

Keywords: ellagic acid; kaempferol; myricetin; prostate cancer; quercetin; rosehip.

\section{Öz}

Amaç: Son zamanlarda yapılan çalışmalarda, doğal kaynak olan fenolik bileşiklerin (kuersetin, kemferol, ellagic asit, mirisetin) prostat kanseri tedavisinde ve kemoprevansında kullanılması önerilmiştir. Kuşburnu bu fenolik molekülleri yüksek konsantrasyonda içerdiğinden, kuşburnu çayının olası anti-proliferatif etkisini prostat kanseri hücre hattında araştırmayı amaçladık.

Gereç ve Yöntem: Kuşburnu çayının farklı sıcaklık ve zaman aralığında hazırlanmış örneklerinin flavonol içeriğini belirledik, daha sonra hazırlanan çayların antiproliferatif etkisi, prostat kanseri hücre hattına çay örnekleri eklenerek belirlendi (VCaP and LNCaP).

Bulgular: Hücre kültürü çalışması için en yüksek kuersetin, ellagik asit ve kemferol seviyelerine sahip 7 dakika kaynatılan parçalanmış meyve ve en yüksek kamferol ve ellagik asit seviyelerine sahip 7 dakika kaynatılan taze meyve seçildi. Çay örnekleri, IC50 değerlerine uygun konsantrasyonda hazırlandı, VCaP ve LNCaP hücre hattında çalışıldı. Kuersetin, LNCaP hücresinde $\mathrm{VCaP}$ hücresine göre daha etkili olduğu belirlendi (sırasıyla, IC50 $=20 \mu \mathrm{M}$ ve $200 \mu \mathrm{M}$ ). Kuşburnu çaylarının VCaP hücreleri üzerindeki antiproliferatif etkisi, LNCaP hücrelerinden biraz daha güçlü etkiye sahip olduğu belirlendi. 
Sonuçlar: Flavonollerin her biri tek başına anti-proliferatif etki göstermektedir. Verilerimiz tüm flavonollerin doğal bir kaynağı olan kuşburnunun androjene duyarlı prostat kanseri üzerinde anti-proliferatif etkisi olduğunu göstermiştir. Kanser tedavisinde doğal kaynakların kullanılması önemli olduğu için kuşburnu prostat kanseri tedavisinde kullanılabilecek umut verici bir doğal ürün gibi görünmektedir.

\section{Introduction}

Prostate cancer is the second most common type of cancer in the world after lung cancer [1-3]. Androgen and androgen receptors have been demonstrated to induce the development and progression of cancer. Current treatment protocols have focused on reducing androgen and androgen receptors [1]. Although the ailment has been treated with chemotherapeutics and other invasive protocols, the death rate is relatively high and preventive approaches through the use of dietary substances become more important in controlling it [2]. Recent studies have shown that diet with phenolic acid is associated with a lower risk of prostate cancer $[4,5]$.

Rosehip, a fruit of the Rose genus of the Rosaceae family, has been widely used for their antioxidant and antiinflammatory effects across Europe [6, 7]. Different types, especially the most common type Rosa canina is cultivated in the Aegean region of Turkey. Rosehips have been proven to have antiproliferative properties against different types of cancer due to its content of vitamin $\mathrm{C}$ and $\mathrm{E}$ and phenolic compounds [7, 8].

Experimental studies have shown that rosehip is a rich in flavonols (a class of phenolic phytochemicals in terms of quercetin, kaempferol, myricetin, and fisetin) and ellagic acid (EA) of phenolic acids. The most abundant flavonoids are quercetin and kaempferol, followed by myricetin [7-9]. In vitro studies exhibited that flavonols (quercetin, kaempferol, or myricetin) could inhibit invasion, migration and signaling molecules involved in cell proliferation in prostate cancer [5]. EA present in fruits and berries is a polyphenolic compound, which has anti-cancer effects in several types of human cancers, i.e., cancers of the esophagus, colon, skin, breast and prostate [10-15].

The most common way to use rosehip extract is to prepare tea with hot water. Experimental studies showed that brewing conditions influenced the amount of phenolic compounds extracted from the rosehip fruit [6-10]. İlyasoğlu et al. (2017) suggested that infusion time and water temperature influenced the antioxidant properties of rosehip teas [6].
The aim of this study was to investigate the effect of rosehip tea on cell survival in prostate cancer cell lines, which are sensitive to androgen receptors. The major compounds (quercetin, kaempferol, myricetin, and EA) in rosehip teas were determined at different infusion times and brewing conditions. Moreover, tea samples including the highest amount of flavonols were used to measure the antiproliferative effect of rosehip.

\section{Materials and methods}

\section{Chemicals and cell culture}

Commercial phenolic compounds quercetin, kaempferol, myricetin, and EA were purchased from Fluka Co. Ltd., Germany and Sigma Co. Ltd., USA.

Human androgen-dependent prostate cancer cell lines, VCaP and LNCaP bought from The American Type Culture Collection (ATCC, Manassas, VA, USA) were used in the study. LNCaP cells were cultured in RPMI 1640 medium (Biological Industries, Kibbutz BeitHaemek, Israel) containing 1\% L-glutamine, $1 \%$ penicillin/streptomycin, 10\% heat inactivated fetal bovine serum (FBS). VCaP cells were cultured in DMEM medium (Biological Industries, Kibbutz BeitHaemek, Israel) containing 1\% L-glutamine, 1\% penicillin/streptomycin, 10\% heat inactivated FBS. The cells were cultivated in a humidified incubator in an environment with $95 \%$ air and $5 \% \mathrm{CO}_{2}$ at $37^{\circ} \mathrm{C}$.

\section{Preparation of rosehip tea}

Rosehip teas were prepared under the following procedures. Fresh fruit collected from Aegean region of Turkey and dried fruit as commercially available fruit was purchased from local market.

The fresh fruits were both steeped as whole and as a shredded fruit using a knife. Both types of rosehip $(1 \mathrm{~g})$ were steeped with $10 \mathrm{~mL}$ distilled water for 1, 3, 5, 7 and 10 min at different steeping temperatures of $80{ }^{\circ} \mathrm{C}$ and $100{ }^{\circ} \mathrm{C}$.

\section{Determination of quercetin, kaempferol, myricetin, and ellagic acid}

Phenolic compound content of the teas were analyzed using LC-MS MS system [11]. The stock standards were prepared at $1 \mathrm{mg} / \mathrm{mL}$ concentration as stock and standard mixtures were made ready by dilution of $1 / 1,000$. The DMAE Caffeate as internal standard was added to all samples to determine the loss of phenolic compounds due to matrix effect. Tea samples were diluted by $10 \mu \mathrm{L}$ with methanol and standard mixtures. A linear gradient method has been used for $\mathrm{MetOH} /$ Water mobile phase at a flow rate of $0.3 \mathrm{~mL} / \mathrm{min}$ with ACQUITY UPLC BEH C18 $(100 \times 2.1 \mathrm{~mm}, 1.7 \mu \mathrm{m})$ column at $40{ }^{\circ} \mathrm{C}$. The method took $5 \mathrm{~min}$, starting with $100 \%$ water and a $1 \mathrm{~min}$ wash then gradually increasing the amount of MetOH and continuing 100\% MetOH for $3 \mathrm{~min}$. The target phenolic compounds investigated were quercetin, kaempferol, myricetin and EA. The specification of phenolic compounds and their 
related MRM values was shown in supplementary file (Table 1 in Supplementary file).

\section{Real-time cytotoxicity assay}

The xCELLigence Real-Time Cell Analyzer (RTCA) DP system (ACEA Biosciences) was employed to determine the cytotoxic effects of EA, kaempferol, myricetin, and quercetin on VCaP and LNCaP cells. The cells were seeded in 96 well e-plate $\left(6.25 \times 10^{3} \mathrm{VCaP}\right.$ cells/well, $2.5 \times 10^{4} \mathrm{LNCaP}$ cells/well). Twenty four hours later, cells were treated with 100-3.125 $\mu \mathrm{M}$ doubling dilutions of quercetin, kaempferol, myricetin, and EA, and were monitored every $15 \mathrm{~min}$ for $72 \mathrm{~h}$. Calculation of $\mathrm{IC}_{50}$ values was obtained by the RTCA Software v 1.2.1.

\section{Real-time growth inhibition assay}

The xCELLigence system was used in order to determine the growth inhibition effects of Rosehip teas on VCaP and LNCaP cells. The cells were seeded in 96 well e-plate $\left(6.25 \times 10^{3} \mathrm{VCaP}\right.$ cells/well, $2.5 \times 10^{4} \mathrm{LNCaP}$ cells/well). Twenty four hours later, cells were treated with 100, 50 and $25 \%$ concentration of Rosehip teas and were monitored every $15 \mathrm{~min}$ for $72 \mathrm{~h}$. Growth inhibition effects of Rosehip teas were assessed by the RTCA Software v 1.2.1.

\section{Statistical analysis}

Statistical analyses were performed using GraphPad Prism 7.01 (GraphPad Software, Inc., San Diego, CA). p values were calculated by two-way ANOVA using the Tukey test for multiple comparisons.

\section{Results}

\section{LC MS/MS results}

The content of phenolic molecules in rosehip teas obtained with boiling and steeping at different time points was presented in supplementary file (Figure 1 in Supplementary file).

The amount of phenolic compounds extracted by boiling was higher than that of steeping. Our data showed that all flavonols were high in commercial boiled tea samples (dry rosehip) regardless of the weather. However, their highest levels in steeped commercial tea were observed in 3rd min. On the other hand, quercetin, EA, and kaempferol levels were maximum in shredded fruit between 5 and 7 min and kaempferol and EA levels were highest in boiled fruit in 7 th $\mathrm{min}$ in boiling water. Accordingly, cell culture studies selected the four tea samples with the highest phenolic compounds in fruit, by boiling fresh fruit for $7 \mathrm{~min}$, shredded one for $5 \mathrm{~min}$, commercial tea for $7 \mathrm{~min}$ and commercial tea steeped for $3 \mathrm{~min}$. Rosehip tea samples were freshly prepared before using for
Table 1: The flavonol concentration of tea samples which were added into cell line $(\mu \mathrm{mol} / \mathrm{L})$.

\begin{tabular}{lcccc}
\hline & Quercetin & Kaempferol & $\begin{array}{r}\text { Ellagic } \\
\text { acid }\end{array}$ & Myricetin \\
\hline $\begin{array}{l}\text { Boiled fruit tea-7 min } \\
\text { Boiled shredded fruit } \\
\text { tea-5 min }\end{array}$ & 9.45 & 1.38 & 0.18 & 0.04 \\
$\begin{array}{l}\text { Boiled commercial } \\
\text { tea-7 min }\end{array}$ & 51.8 & 2.68 & 0.11 & 0.03 \\
$\begin{array}{l}\text { Steeped commercial } \\
\text { tea-3 min }\end{array}$ & 50.4 & 2.35 & 1.35 & 1.95 \\
\hline
\end{tabular}

cell growth inhibition tests. Table 1 presents the final concentrations of flavonols in rosehip tea samples to be added to cell culture.

\section{Cytotoxic effects of commercial phenolic compounds on VCaP and LNCaP cells}

Cytotoxic effects of quercetin, kaempferol, myricetin, and EA were determined based on the dose-response curves of the normalized cell index for 24th, 48th, and $72 \mathrm{nd} h$ by the RTCA Software. The $\mathrm{IC}_{50}$ values of the calculated commercial phenolic compounds are shown in Tables 2 and 3, and the dose-response curves in supplementary file (Figures 2 and 3 in Supplementary file).

Table 2: $\mathrm{IC}_{50}$ values for commercial phenolic compounds in VCaP cell culture.

\begin{tabular}{llll}
\hline & 24th $\mathbf{h}$ & 48th $\mathbf{~}$ & 72nd $\mathbf{h}$ \\
\hline Quarcetin & $193 \mu \mathrm{M}$ & $343 \mu \mathrm{M}$ & $204 \mu \mathrm{M}$ \\
Kaempferol & $4.17 \mu \mathrm{M}$ & $5.74 \mu \mathrm{M}$ & $2.06 \mu \mathrm{M}$ \\
Miricetin & $17 \mu \mathrm{M}$ & $24.5 \mu \mathrm{M}$ & $30.8 \mu \mathrm{M}$ \\
Ellagic acid & $25.9 \mu \mathrm{M}$ & $45.4 \mu \mathrm{M}$ & $11.8 \mu \mathrm{M}$ \\
\hline
\end{tabular}

Table 3: $\mathrm{IC}_{50}$ values for commercial phenolic compounds in LNCaP cell culture.

\begin{tabular}{llll}
\hline & 24th $\mathbf{h}$ & 48th $\mathbf{h}$ & 72nd $\mathbf{h}$ \\
\hline Quarcetin & $14.5 \mu \mathrm{M}$ & $31.7 \mu \mathrm{M}$ & $32.2 \mu \mathrm{M}$ \\
Kaempferol & $33.3 \mu \mathrm{M}$ & $28.3 \mu \mathrm{M}$ & $26.2 \mu \mathrm{M}$ \\
Miricetin & $53.8 \mu \mathrm{M}$ & $55.3 \mu \mathrm{M}$ & $54.5 \mu \mathrm{M}$ \\
Ellagic acid & $23.9 \mu \mathrm{M}$ & $24.3 \mu \mathrm{M}$ & $24.7 \mu \mathrm{M}$ \\
\hline
\end{tabular}




\section{The growth inhibition effects of Rosehip teas on VCaP and LNCaP cells}

The growth inhibition effects of rosehip tea were studied considering changes in cell index in time and dosedependent form using RTCA software. The lower slope plots $(1 / \mathrm{h})$ presented growth inhibition effects of rosehip teas, as shown in Figures 1 and 2.

\section{Discussion}

Prostate cancer is the most common cancer among males. It is estimated that one in six will be diagnosed with prostate cancer in their lifetime [3]. Therefore, the studies focus on treatment and prevention of prostate cancer. Prostate cancer's growth, invasion and metastasis have been shown to be inhibited by flavonols (quercetin, kaempferol, myricetin, and fisetin), especially the potential use of fisetin to treat androgen-dependent prostate cancer currently under study $[1,4,5,12,13]$. The present study investigated the possible anti-proliferative effect of rosehip tea with high amounts of aforementioned flavonols (quercetin, kaempferol, myricetin, and fisetin) on prostate cancer cell line.

Many studies have recently suggested that Rosehip have anti-cancer, anti-inflammatory and anti-oxidant activities both in clinical and in-vitro studies [6, 14]. Rosehip extracts were traditionally consumed as tea using hot

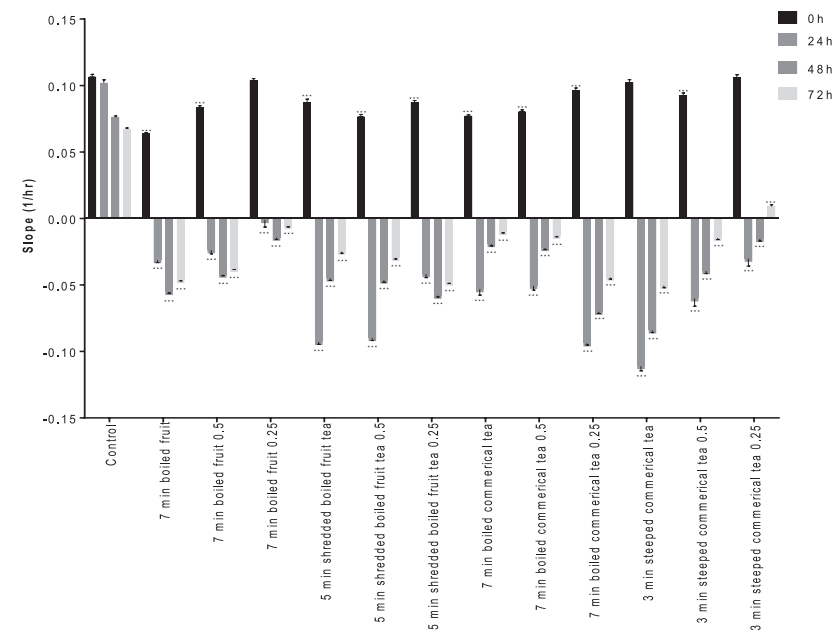

Figure 1: Rosehip tea represses the cell index and proliferation of VCaP cells. The slope $(1 / h)$ describes the rate of change of the cell index for cells after rosehip tea treatment ( $24 \mathrm{th} \mathrm{h}$ ) calculated from period $0-24 \mathrm{~h}, 24-48 \mathrm{~h}, 48-72 \mathrm{~h}$ and $72-96 \mathrm{~h}$. The results are representative of three independent experiments. ${ }^{*} p<0.01$, ${ }^{* *} p<0.001$ and ${ }^{* \star *} p<0.0001$. water. Recent studies have exhibited that brewing conditions affect the phenolic compound content as well as its anti-oxidant capacity [6, 7]. Our study showed that the higher amount of phenolic compound was obtained by boiling than in steeping. However, the levels of phenolic compounds in rosehip tea decreased after boiling more than $7 \mathrm{~min}$.

Concentration of EA increased whereas that of myricetin decreased by boiling extract. We found that the highest myricetin content was acquired in 3 min steeped commercial tea and in $5 \mathrm{~min}$ boiled commercial tea. İlyasoğlu et al. observed that total phenolic content (TPC) increased with increasing time up to a certain degree and then changed slightly [6]. While the TPC was highest at times between 5.5 and $10 \mathrm{~min}$ and at temperatures between 77 and $86^{\circ} \mathrm{C}$, antioxidant activity (ferric-reducing antioxidant power) was highest at brewing time for 6-8 $\mathrm{min}$ and between 84 and $86^{\circ} \mathrm{C}$.

Our data showed that the same concentration of phenolic compounds in every period of time effected cell viability (Tables 2 and 3 ). We showed that $\mathrm{IC}_{50}$ concentration for myricetin in LNCaP cell culture was higher than that of other phenolic molecules. The trend in VCaP cells was observed to be completely different from LNCaP cells. $\mathrm{IC}_{50}$ concentration of quercetin, kaempferol, and EA at $48 \mathrm{~h}$ was higher than at $24 \mathrm{~h}$ and $72 \mathrm{~h}$ but that of myricetin $\mathrm{IC}_{50}$ at $72 \mathrm{~h}$ was maximum (Table 2). The quercetin $\mathrm{IC}_{50}$ concentration related to $\mathrm{VCaP}$ cell culture is higher than in other phenolic molecules extracted from rosehip tea.

The tea samples were added to the cell cultures in three different concentrations (direct, $1 / 2$, and $1 / 4$ ) prepared by diluting them with culture medium and the cell viability monitored in 24, 48, and $72 \mathrm{~h}$ after with the addition of the samples. The data of the study was shown in Figure 1 for VCaP cells and in Figure 2 for LNCaP cells.

The results showed that 3 min-steeped commercial tea caused the repression of cell index and proliferation rate of LNCaP cells to be significantly higher than in other experimental groups over $24 \mathrm{~h}$, in particular (Figure 2). No differences exist between 3 min steeped commercial tea (1/4) and control groups. We concluded that $7 \mathrm{~min}$ boiled commercial tea, 7 min boiled commercial tea (1/2), $3 \mathrm{~min}$ steeped commercial tea, 3 min steeped commercial tea (1/2) and $7 \mathrm{~min}$ boiled fruit (1/4) have highest impact on reduction of cell index and proliferation rate of $\mathrm{LNCaP}$ cells in comparison with other experimental groups. Seven minutes boiled commercial tea and 3 min steeped commercial tea of highest EA, quercetin, and myricetin content were the most effective ones. Lansky et al. observed that EA inhibited the invasion of human androgen-independent prostate cancer, PC3 cells, in vitro [15]. Since the affinity of 


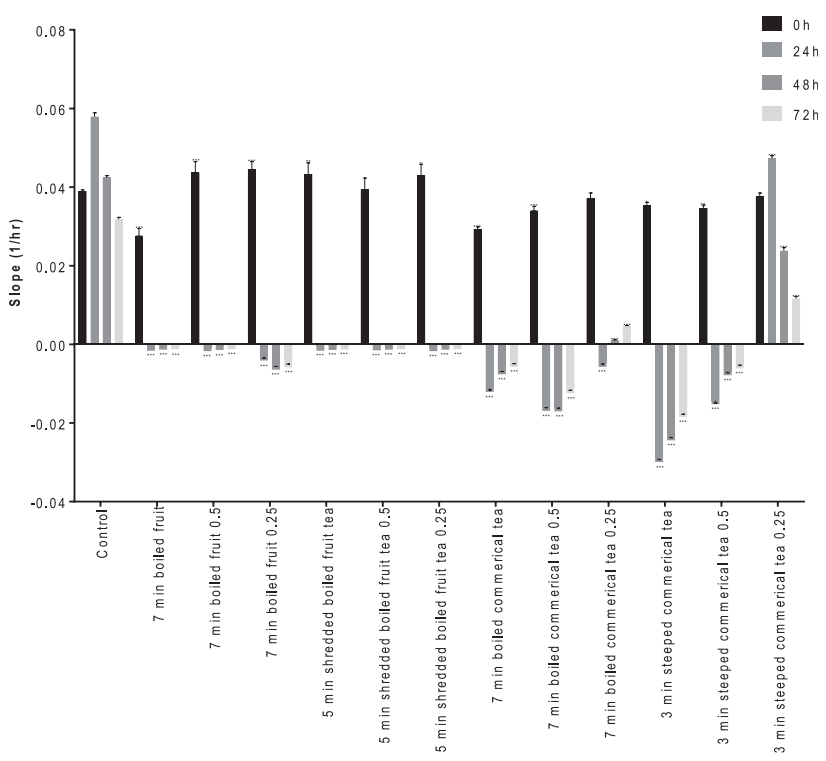

Figure 2: Rosehip tea represses the cell index and proliferation of LNCaP cells. The slope $(1 / h)$ describes the rate of change of the cell index for cells after rosehip tea treatment ( 24 th $\mathrm{h}$ ) calculated from period $0-24 \mathrm{~h}, 24-48 \mathrm{~h}, 48-72 \mathrm{~h}$ and $72-96 \mathrm{~h}$. The results are representative of three independent experiments. ${ }^{*} p<0.01$, ${ }^{* *} p<0.001$ and ${ }^{* * *} p<0.0001$.

EA to prostate is high, EA might accumulate in prostate tissue and is thus proposed as an anticancer agent for prostate.

EA with inhibitory properties against the collagenase/ gelatinase might prevent the metastasis of tumor by reducing the motility and the invasion of the cells LNCaP cell-line is an androgen-responsive prostate cancer cell. The acid expresses androgen receptor and androgeninducible genes. Quercetin has antiproliferative effect by blocking signal transduction pathways especially Inositol $1,4,5$ triphosphate $[5,16]$. The study determined that quercetin was more effective in $\mathrm{LNCaP}$ cell $\left(\mathrm{IC}_{50}=20 \mu \mathrm{M}\right)$ than VCaP cell line $\left(\mathrm{IC}_{50}=200 \mu \mathrm{M}\right)$. Xing et al. showed that quercetin treatment inhibited the transcription of Androgen receptors in LNCaP cells and down-regulated the androgen related proteins (Prostate specific antigen, $\mathrm{Hu}$ man glandular kallikrein) which regulate tumor cell growth, invasion and osteoblastic metastasis [17]. Although myricetin and EA levels have been found to be the highest in concentration in boiled and steeped commercial tea samples, they are lower than at their $\mathrm{IC}_{50}$ levels. The antiproliferative effect of the tea samples were consequently concluded to be likely to be associated with their quercetin and kaempferol content, which was evidenced by our data to show that the effect of phenolic molecules on VCaP cells (Figure 1 in supplemental file) were slightly stronger than that of LNCaP cells, as compared to their $\mathrm{IC}_{50}$ levels (Table 3). Supplemented Figure 1 shows shredded boiled fruit sample with the same concentration of kaempferol but lower concentration of EA, myricetin, and quercetin with the other tea samples strongly inhibits cell growth in VCaP cells. Kaempferol has been shown to reduce testosterone levels by inhibiting $5 \alpha$-reductase isoenzyme 2 [5].

It is interesting to note that, the cell index and proliferation rate improved slightly in both cell lines during the time period (from 24 to 72), which could be accounted for by the acquisition of cell resistance in response to phenolic molecules by activating of unknown genes and cell signaling pathways. Another explanation could be that phenolic compounds must have accumulated over time.

No matter what the influence of each flavonol on prostate cancer could be, it can be speculated that the combined effect was stronger than individual effect of each flavonol. It is therefore recommended to use natural sources for treatment strategies rather than artificial molecules.

In conclusion, the results of the study showed that rosehip tea reduced growth and cell proliferation in the line of prostate cancer cells which are sensitive to androgens. Although we did not investigate the case by highlighting the mechanism of inhibition of cell growth in cell levels by flavonols in rosehip, our data clearly indicated that rosehip tea as a natural source of flavonols could be recommended to manage prostate cancer.

Despite the fact that amount extracted from phenolic molecules changes based on the preparation techniques and timing, the optimal conditions are required to be determined for acquisition of the highest possible concentration of flavonols before using for treatment. Further research is needed to determine the value of rosehip tea for treatment of prostate cancer in vivo.

Research funding: None declared.

Author contributions: AM Özgönül wrote the paper, A.Aşık and R. Aslaminabad performed cell culture study, B.Durmaz prepared tea samples and performed LC MS/ MS measurement, C.Gündüz analysed data, EY Sözmen designed the analysis and contributed data.

Conflict of Interest: There are no conflicts of interest among the authors.

\section{References}

1. Chhabra G, Singh CK, Ndiaye MA, Fedorowicz S, Molot A, Ahmad N. Prostate cancer chemoprevention by natural agents: clinical evidence and potential implications. Cancer Lett 2018;422:9-18. 
2. Malik A, Afaq S, Shahid M, Akhtar K, Assiri A. Influence of ellagic acid on prostate cancer cell proliferation: a caspase-dependent pathway. Asian Pac J Trop Med 2011;4:550-5.

3. Siegel RL, Miller KD, Jemal A. Cancer statistics. CA Cancer J Clin 2018;68:7-30.

4. Russo G, Campisi D, Di Mauro M, Regis F, Reale G, Marranzano M, et al. Dietary consumption of phenolic acids and prostate cancer: a case-control study in Sicily, Southern Italy. Molecules 2017;22:2159.

5. Boam T. Anti-androgenic effects of flavonols in prostate cancer. Ecancermedicalscience 2015;9:585.

6. İlyasoğlu H, Arpa TE. Effect of brewing conditions on antioxidant properties of rosehip tea beverage: study by response surface methodology. J Food Sci Technol 2017;54:3737-43.

7. Lantano C, Rinaldi M, Cavazza A, Barbanti D, Corradini C. Effects of alternative steeping methods on composition, antioxidant property and colour of green, black and oolong tea infusions. J Food Sci Technol 2015;52:8276-83.

8. Hajiaghaalipour F, Sanusi J, Kanthimathi MS. Temperature and time of steeping affect the antioxidant properties of white, green, and black tea infusions. J Food Sci 2016;81:H246-54.

9. Kelebek H. LC-DAD-ESI-MS/MS characterization of phenolic constituents in turkish black tea: effect of infusion time and temperature. Food Chem 2016;204:227-38.

10. Sharpe E, Hua F, Schuckers S, Andreescu S, Bradley R. Effects of brewing conditions on the antioxidant capacity of twentyfour commercial green tea varieties. Food Chem 2016;192: 380-7.

11. Castro C, Mura F, Valenzuela G, Figueroa C, Salinas R, Zuñiga MC, et al. Identification of phenolic compounds by HPLC-ESI-MS/MS and antioxidant activity from chilean propolis. Food Res Int 2014;64:873-9.
12. Senthilkumar K, Arunkumar R, Elumalai P, Sharmila G, Gunadharini DN, Banudevi S, et al. Quercetin inhibits invasion, migration and signalling molecules involved in cell survival and proliferation of prostate cancer cell line (PC-3). Cell Biochem Funct 2011;29:87-95.

13. Cheng T-C, Lu J-F, Wang J-S, Lin L-J, Kuo H-I, Chen B-H. Antiproliferation effect and apoptosis mechanism of prostate cancer cell PC-3 by flavonoids and saponins prepared from Gynostemma pentaphyllum. J Agric Food Chem 2011;59: 11319-29.

14. Tumbas VT, Canadanovic-Brunet JM, Cetojevic-Simin DD, Cetkovic GS, Ethilas SM, Gille L. Effect of rosehip (Rosa canina L.) phytochemicals on stable free radicals and human cancer cells. J Sci Food Agric 2012;92:1273-81.

15. Lansky EP, Harrison G, Froom P, Jiang WG. Pomegranate (Punica granatum) pure chemicals show possible synergistic inhibition of human PC-3 prostate cancer cell invasion across Matrigel $^{\mathrm{TM}}$. Invest New Drugs 2005;23:121-2.

16. Yuan H, Young CYF, Tian Y, Liu Z, Zhang M, Lou H. Suppression of the androgen receptor function by quercetin through proteinprotein interactions of Sp1, c-Jun, and the androgen receptor in human prostate cancer cells. Mol Cell Biochem 2010;339: 253-62.

17. Xing N, Chen Y, Mitchell SH, Young CY. Quercetin inhibits the expression and function of the androgen receptor in LNCaP prostate cancer cells. Carcinogenesis 2001;22:409-14.

Supplementary material: The online version of this article offers supplementary material (https://doi.org/10.1515/tjb-2019-0262). 